\title{
Analysis of Deep Groundwater in the Sambagawa Belt in Relation to Growth of Komatsuna (Brassica rapa var. perviridis)
}

\author{
Midori HiKaSHI ${ }^{1}$ and Katsumi IsHIKAWA ${ }^{2}$ \\ The United Graduate School of Agricultural Sciences, Ehime University, 3-5-7 Tarumi, Matsuyama, Ehime 790-8566, Japan \\ ${ }^{2}$ Faculty of Agriculture, Kochi University, B-200 Monobe, Nankoku, Kochi 783-8502, Japan
}

(Received March 14, 2014; Accepted April 22, 2014)

\begin{abstract}
The quality of groundwater is essential to ensuring the sustainable use of water resources for irrigation. Deep groundwater samples were collected from the Sambagawa Belt in southeastern Japan, at $1,180 \mathrm{~m}\left(\mathrm{GW}_{\text {deep }}\right)$ and $50 \mathrm{~m}\left(\mathrm{GW}_{\text {shallow }}\right)$. Groundwater quality was assessed based on analysis of physicochemical parameters. The sodium adsorption ratio of groundwater fell in the range of 1.61-3.13, while electric conductivity of $\mathrm{GW}_{\text {deep }}$ was high $\left(>75.0 \mathrm{mS} \mathrm{m}^{-1}\right)$. Experiments were performed to determine the effects of deep groundwater on germination and early growth of komatsuna (Brassica rapa var. perviridis). Strong inhibition (44\% reduction) of root growth was observed with $\mathrm{GW}_{\text {deep }}$ compared to the control treatment. In contrast, shoot length increased with increasing depth of the groundwater source. Comparison of the effects of $\mathrm{GW}_{\text {deep }}$ and $\mathrm{NaCl}$ solution on growth of komatsuna revealed similar patterns at $1 \times 10^{3} \mathrm{mg} \mathrm{L}^{-1} \mathrm{NaCl}$ solution. Our findings suggested that deep groundwater can be used for irrigation of komatsuna, but not during the germination stage of this crop.
\end{abstract}

Keywords : irrigation water, komatsuna, nursery plant, salinity stress, sodium chloride, water quality

\section{INTRODUCTION}

Fresh-water resources are becoming increasingly limited as human consumption of these resources, and their use in agriculture and other industries, increase. Water is becoming scarce not only in arid and drought-prone areas but also in regions that were not previously water-limited (Pereira et al., 2002), because degradation of water quality by salinization and nutrient loading has made freshwater increasingly unavailable (Scanlon et al., 2007). Therefore, water scarcity refers to both the quantity and quality of water available for stringent to meet various needs. Deterioration of aquatic environments is accompanied by health risks (Zamberlan da Silva et al., 2008; Nahar and Zhang, 2012). Degraded water quality is often associated with water shortages (Pereira et al., 2002) and increased damage to natural ecosystems. Agricultural production consumes approximately $70 \%$ of available global freshwater resources (Ongley, 1996; Kanae, 2009), including surface water and groundwater.

Groundwater has come to be an important source of irrigation water for agriculture in large parts of Asia. Over $300 \mathrm{~km}^{3}$ of groundwater is used annually in India, Nepal, Bangladesh, Pakistan, and China, close to half of the world's total annual use (Shah et al., 2003). Groundwater is less easily polluted than surface water because it is protected naturally, is less affected by drought even when close to the point of use, and does not require extensive treatment before use; therefore, groundwater is a more reli- able resource than surface water (Ravikumar et al., 2011). A number of studies conducted in various countries have examined groundwater quality in relation to drinking and irrigation (Subramani et al., 2005; Ketata et al., 2012; Alaya et al., 2013). Groundwater chemistry provides important information on the suitability of the water for drinking and for agricultural and industrial purposes. Studies of groundwater chemistry have been conducted in Japan to assess groundwater quality (Mitra et al., 2007a, 2007b; Nahar and Zhang, 2012).

Some recent studies have focused on "deep groundwater," because knowledge about this resource can facilitate the development of water supplies and geothermal energy, and planning for underground waste injection or nuclear waste repositories (Rahman et al., 2011; Alley et al., 2013). Deep groundwater is poorly defined, but there is growing interest in understanding the typical depths from which groundwater is withdrawn to meet various demands for this resource (Alley et al., 2013). Development of the term "deep groundwater" is tied to the advance of the early groundwater sciences in the middle of the nineteenth century (Hebig et al., 2012). Research on deep groundwater flow in major hydrogeological units is important to maintaining the ability to provide water for human consumption and to adapt its utilization for agricultural practices. However, extensive study of the effects of deep groundwater quality on growth of crop plants has not been conducted. Water quality can present a major problem in agriculture, particularly in hydroponic culture, because of contamination by inorganic and organic pollutants.

Corresponding author: Midori Hikashi, fax: +81-88-864-5111, e-mail : mido_4696@yahoo.co.jp 
Analysis of irrigation water quality is essential for hydroponic culture regardless of the water source.

Assessments of the quality and suitability of deep groundwater are needed to develop applications for its use in agriculture. This work represents a first attempt to assess the quality of deep groundwater and its effects on germination and early plant growth. Several environmental parameters, including salinity (Chartzoulakis and Klapaki, 2000; Jamil et al., 2007), heavy metal toxicity (Ling et al., 2010), and temperature (Zhang et al., 2010) can inhibit or reduce seed germination and seedling emergence. Generally, plants are more sensitive to salinity during germination and early seedling growth than during later vegetative growth stages (Hayward and Bernstein, 1958). Hence, seed germination tests can provide a quick assay for water quality.

The main objectives of the present study were to (1) assess the physicochemical quality of deep groundwater in Wakayama, southeastern Japan, and (2) determine the effects of deep groundwater on the germination and early growth of komatsuna (Brassica rapa var. perviridis), a typical Japanese leafy vegetable for commercial purposes.

\section{MATERIALS AND METHODS}

\section{Sampling water}

Deep groundwater samples were taken from the Sambagawa Belt in Kounono, Wakayama Prefecture, Japan $\left(34^{\circ} 18^{\prime} \mathrm{N}, 135^{\circ} 34^{\prime} \mathrm{E}\right.$; Fig. 1$)$ at two depths, $1,180 \mathrm{~m}$ $\left(\mathrm{GW}_{\text {deep }}\right)$ and $50 \mathrm{~m}\left(\mathrm{GW}_{\text {shallow }}\right)$, and spring water $\left(\mathrm{GW}_{\text {spring }}\right)$ was collected from the same sampling point. Groundwater samples were immediately transported to the laboratory at Kochi University, Kochi Prefecture, Japan $\left(33^{\circ} 33^{\prime} \mathrm{N}, 133^{\circ}\right.$ $\left.40^{\prime} \mathrm{E}\right)$. Pure water (PW) was prepared using an ultrapure water system (SIMSV0000; Millipore, MA, USA). The resistivity of PW was $18.2 \mathrm{M} \Omega$, and the average $\mathrm{pH}$ and electrical conductivity (EC) were 7.30 and $0.039 \mathrm{mS} \mathrm{m}^{-1}$, respectively. Tap water (TW) was collected at the Faculty of Agriculture, Kochi University. The average $\mathrm{pH}$ and EC of the TW were 6.82 and $18.24 \mathrm{mS} \mathrm{m}^{-1}$, respectively, in 2009-2011.

Physicochemical parameters of deep groundwater

The $\mathrm{pH}, \mathrm{EC}$, and oxidation-reduction potential (ORP) of groundwater samples were measured using PHL-10, CM-30G, and HM-25G meters, respectively (DKK-TOA, Tokyo, Japan). The reference electrode for the ORP meter was $\mathrm{Ag}$ vs. $\mathrm{AgCl}_{2}$.

The concentrations of ions in $\mathrm{GW}_{\text {deep }}, \mathrm{GW}_{\text {shallow }}$, and $\mathrm{GW}_{\text {spring }}$ samples were analyzed by ion chromatography (IA200, DKK-TOA). Groundwater samples were filtered through $20-\mu \mathrm{m}$ and $45-\mu \mathrm{m}$ filter units (DISMIC, Advantec, Tokyo, Japan) before analysis. We analyzed six cations $\left(\mathrm{Li}^{+}, \mathrm{Na}^{+}, \mathrm{NH}_{4}^{+}, \mathrm{K}^{+}, \mathrm{Mg}^{2+}\right.$, and $\left.\mathrm{Ca}^{2+}\right)$ and seven anions $\left(\mathrm{PO}_{4}{ }^{3-}, \mathrm{F}^{-}, \mathrm{Cl}^{-}, \mathrm{NO}_{2}{ }^{2-}, \mathrm{Br}^{-}, \mathrm{NO}_{3}{ }^{-}\right.$, and $\left.\mathrm{SO}_{4}{ }^{2-}\right) . \mathrm{SiO}_{2}$ was determined by the silicomolybdate method using a portable spectrophotometer (DR2800, Hach, USA). The experiment was conducted in triplicate and the average of the three values was recorded for each parameter. Total hardness (TH) of water is a measure of dissolved $\mathrm{Ca}^{2+}$ and $\mathrm{Mg}^{2+}$, expressed as $\mathrm{CaCO}_{3}$, and was calculated as follows (Hem, 1970; Ravikumar et al., 2011; Alaya et al., 2013):

$\mathrm{TH}\left(\mathrm{mg} \mathrm{L}^{-1}\right)=2.497 \mathrm{Ca}^{2+}+4.115 \mathrm{Mg}^{2+}$

The concentrations of $\mathrm{Ca}^{2+}, \mathrm{Mg}^{2+}$, and $\mathrm{Na}^{+}$were used to determine the suitability of groundwater for agriculture. The sodium adsorption ratio (SAR) was used as a sodium/ alkalinity index, calculated using the following equation (Richards, 1954):

$$
\mathrm{SAR}=\frac{\mathrm{Na}^{+}}{\sqrt{\frac{\mathrm{Ca}^{2+}+\mathrm{Mg}^{2+}}{2}}}
$$

where the ion concentrations are expressed in meq $\mathrm{L}^{-1}$. The SAR is related to the adsorption of sodium by soils, and thus indicates the sodium/alkali hazard of irrigation water (Richards, 1954).

Germination tests

An experiment was established to evaluate the effects of the different water sources on final germination percent-

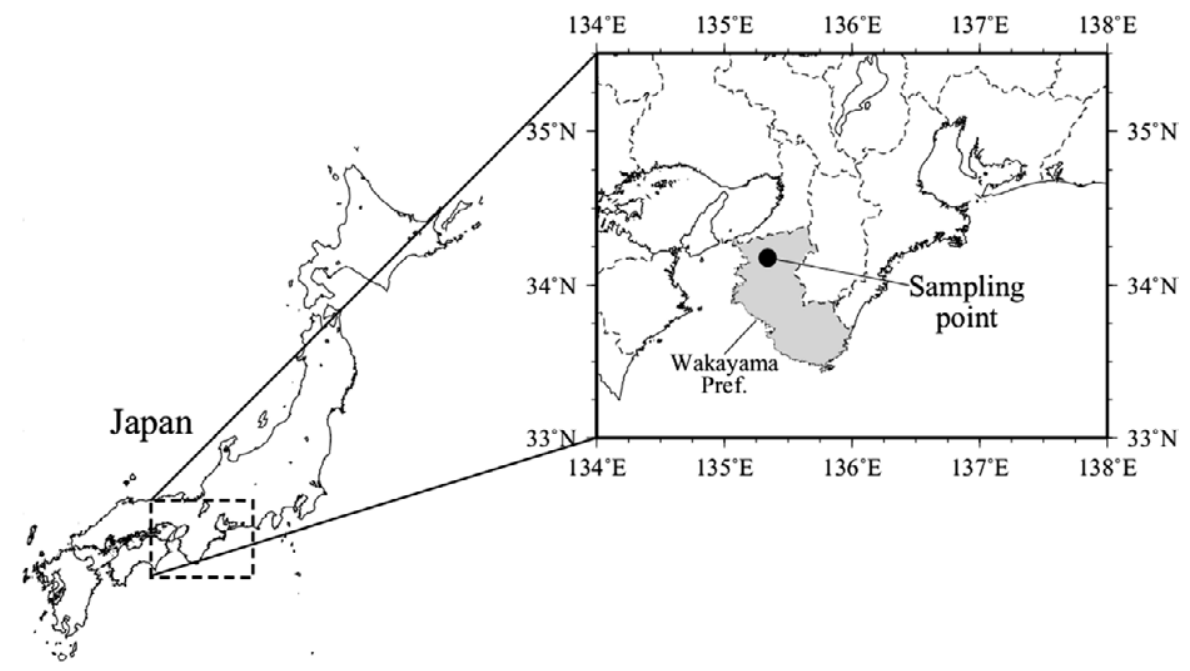

Fig. 1 Location of the groundwater sampling area in southeastern Honshu Island. 
age and seedling, root, and shoot lengths, using seeds of komatsuna (cultivar Natsu Rakuten, Takii Seed Co., Tokyo). We tested samples of PW, TW, $\mathrm{GW}_{\text {deep }}, \mathrm{GW}_{\text {shallow, }}$, and $\mathrm{GW}_{\text {spring. }}$. For comparison with salt stress conditions, $\mathrm{NaCl}$ treatments $\left(1,5,10\right.$, and $\left.15 \times 10^{3} \mathrm{mg} \mathrm{L}^{-1}\right)$ were applied. Filter paper (No. 3, Advantec) was placed in a Petri dish $(80 \mathrm{~mm}$ dia $\times 70 \mathrm{~mm}$ height $)$ with 20 seeds $(n=3$ replicates per water source and salinity treatment). Each dish was moistened with $4 \mathrm{~mL}$ of test water. Germination tests were performed in an incubator (BITEC-400, Shimadzu, Tokyo, Japan) under dark conditions at $25^{\circ} \mathrm{C}$. Petri dishes were covered with lids to prevent evaporation and to minimize changes in the concentrations of the solutions. Final germination (FG) percentage at $72 \mathrm{~h}$ was calculated as follows:

$$
\mathrm{FG}(\%)=\frac{\text { No. of germinated seeds }}{\text { Total No. of seeds }} \times 100
$$

After counting germinated seeds, plant seedlings were removed carefully from the Petri dishes and the lengths of seedlings, roots, and shoots were measured. Seedling length was expressed as the sum of root and shoot length.

\section{Statistical analysis}

Data quantification and statistical analysis were performed using the R Language and Environment for Statistical Computing ver. 3.0.0 (R Development Core Team, Vienna, Austria). We used bivariate correlation analyses to examine the statistical relationships between pairs of variables. Relationships between the various groundwater parameters were assessed using the Spearman rank coefficient, which is based on the ranking of the data rather than on their absolute values (Kumar et al., 2006; Alaya et al., 2013). Data from the analysis of groundwater resources and komatsuna germination tests were assessed by one-way analysis of variance (ANOVA) to determine significant differences $(P<0.05)$ among the water sources and salinity treatments. Significant differences between means were determined using Tukey's honestly significant difference (HSD) test.

\section{RESULTS}

Physicochemical parameters of deep groundwater

Table 1 presents the physicochemical parameters of the groundwater samples. There were no significant differences in $\mathrm{pH}$ between any of the samples. The mean $\mathrm{pH}$ values of the three groundwater sources ranged from 6.86 to 7.87 (close to neutral). The EC of groundwater varied widely, ranging between 18.58 and $131.75 \mathrm{mS} \mathrm{m}^{-1}$. The low values of EC in $\mathrm{GW}_{\text {spring }}$ and TW indicated low mineral content. In contrast, the EC of groundwater samples (particularly $\mathrm{GW}_{\text {deep }}$ ) was higher than that of TW. The mean ORP values of groundwater were between 250 and 300 $\mathrm{mV}$, while the ORP of TW was $>500 \mathrm{mV}$. The TH of TW and $\mathrm{GW}_{\text {spring }}$ was low $\left(<60 \mathrm{mg} \mathrm{L}^{-1}\right)$ while $\mathrm{TH}$ of groundwater ranged from approximately 100 to $400 \mathrm{mg} \mathrm{L}^{-1}$. The SAR values of groundwater ranged between approximately 1.5 and 4.0, while the SAR of TW was $<0.25$ (Table 1).

The major ions found in all water sources were $\mathrm{Na}^{+}$, $\mathrm{K}^{+}, \mathrm{Mg}^{2+}, \mathrm{Ca}^{2+}, \mathrm{Cl}^{-}$, and $\mathrm{SiO}_{2}$ (Table 2). $\mathrm{NH}_{4}{ }^{+}, \mathrm{PO}_{4}{ }^{2+}$, $\mathrm{NO}_{2}{ }^{2-}$, and $\mathrm{Br}^{-}$were not detected in groundwater. The abundance of the major ions in $\mathrm{GW}_{\text {deep }}$ was as follows: $\mathrm{Na}^{+}$ $>\mathrm{SiO}_{2}>\mathrm{Cl}^{-}>\mathrm{Ca}^{2+}>\mathrm{Mg}^{2+}>\mathrm{K}^{+}$. Sodium concentrations in groundwater varied from approximately 25 to $170 \mathrm{mg}$ $\mathrm{L}^{-1}$. The chloride concentration of groundwater was $<85$ $\mathrm{mg} \mathrm{L}^{-1}$. Calcium and magnesium concentrations were significantly higher in $\mathrm{GW}_{\text {deep }}$ than in the other samples. Ion concentrations in groundwater generally increased with increasing depth (Table 2).

A correlation matrix of the nine variables analyzed ( $\mathrm{pH}, \mathrm{EC}, \mathrm{ORP}, \mathrm{Na}^{+}, \mathrm{K}^{+}, \mathrm{Mg}^{2+}, \mathrm{Ca}^{2+}, \mathrm{Cl}^{-}$, and $\mathrm{SiO}_{2}$ ) is provided in Table 3. Coefficients close to +1 or -1 represent a strong correlation, whereas values close to zero indicate no relationship between parameters. In general, geochemical parameters with correlation coefficients $>0.7$ are considered to be strongly correlated, whereas coefficients between 0.5 and 0.7 indicate a moderate correlation (Giridharan et al., 2008). $\mathrm{Na}^{+}, \mathrm{Mg}^{2+}, \mathrm{Ca}^{2+}$, and $\mathrm{Cl}^{-}$were the main ions responsible for the higher $\mathrm{EC}$ of groundwater

Table 1 Physicochemical parameters of deep groundwater $\left(\mathrm{GW}_{\text {decp }}\right.$ and $\left.\mathrm{GW}_{\text {shallow }}\right)$, spring water $\left(\mathrm{GW}_{\text {spring }}\right)$, and tap water (TW).

\begin{tabular}{lcccccc}
\hline & Depth $(\mathrm{m})$ & $\mathrm{pH}$ & $\mathrm{EC}\left(\mathrm{mS} \mathrm{m}^{-1}\right)$ & $\mathrm{ORP}(\mathrm{mV})$ & $\mathrm{TH}\left(\mathrm{mg} \mathrm{L}^{-1}\right)$ & SAR \\
\hline $\mathrm{TW}$ & & $7.29 \pm 0.27^{\mathrm{a}}$ & $15.15 \pm 1.43^{\mathrm{a}}$ & $523 \pm 9^{\mathrm{a}}$ & $57.23 \pm 0.02^{\mathrm{a}}$ & $0.23 \pm 0.00^{\mathrm{a}}$ \\
$\mathrm{GW}_{\text {spring }}$ & 0 & $6.86 \pm 0.38^{\mathrm{a}}$ & $18.58 \pm 0.68^{\mathrm{a}}$ & $265 \pm 4^{\mathrm{b}}$ & $50.01 \pm 0.17^{\mathrm{b}}$ & $1.61 \pm 0.01^{\mathrm{b}}$ \\
$\mathrm{GW}_{\text {shallow }}$ & 50 & $7.30 \pm 0.83^{\mathrm{a}}$ & $33.80 \pm 0.30^{\mathrm{a}}$ & $290 \pm 70^{\mathrm{b}}$ & $106.98 \pm 1.20^{\mathrm{c}}$ & $1.45 \pm 0.14^{\mathrm{b}}$ \\
$\mathrm{GW}_{\text {deep }}$ & 1180 & $7.87 \pm 0.58^{\mathrm{a}}$ & $131.75 \pm 19.08^{\mathrm{b}}$ & $253 \pm 59^{\mathrm{b}}$ & $381.22 \pm 3.98^{\mathrm{d}}$ & $3.82 \pm 0.01^{\mathrm{c}}$ \\
\hline
\end{tabular}

EC, electrical conductivity; ORP, oxidation-reduction potential; TH, total hardness; SAR, sodium adsorption ratio.

Values are means \pm SD $(n=3)$. Different letters for a given parameter indicate significant differences $(P<0.05$,

Tukey's-HSD test).

Table 2 Ion concentrations $\left(\mathrm{mg} \mathrm{L}^{-1}\right)$ in deep groundwater $\left(\mathrm{GW}_{\text {deep }}\right.$ and $\left.\mathrm{GW}_{\text {shallow }}\right)$, spring water $\left(\mathrm{GW}_{\text {spring }}\right)$, and tap water (TW).

\begin{tabular}{|c|c|c|c|c|c|c|c|c|c|}
\hline & $\mathrm{Na}^{+}$ & $\mathrm{K}^{+}$ & $\mathrm{Mg}^{2+}$ & $\mathrm{Ca}^{2+}$ & $\mathrm{F}^{-}$ & $\mathrm{Cl}^{-}$ & $\mathrm{NO}_{3}{ }^{-}$ & $\mathrm{SO}_{4}{ }^{2-}$ & $\mathrm{SiO}_{2}$ \\
\hline TW & $4.04 \pm 0.01^{\mathrm{a}}$ & $0.97 \pm 0.02^{\mathrm{a}}$ & $1.68 \pm 0.01^{\mathrm{a}}$ & $20.2 \pm 0.0^{\mathrm{a}}$ & $0.02 \pm 0.02^{\mathrm{a}}$ & $4.27 \pm 0.25^{\mathrm{a}}$ & $1.82 \pm 0.02^{\mathrm{a}}$ & $7.28 \pm 0.04^{\mathrm{a}}$ & $6.45 \pm 0.07^{\mathrm{a}}$ \\
\hline $\mathrm{GW}_{\text {spring }}$ & $26.37 \pm 0.06^{\mathrm{b}}$ & $1.93 \pm 0.36^{\mathrm{a}}$ & $4.54 \pm 0.01^{\mathrm{b}}$ & $12.7 \pm 0.1^{\mathrm{b}}$ & $0.53 \pm 0.10^{\mathrm{a}}$ & $10.87 \pm 0.21^{\mathrm{b}}$ & $1.24 \pm 1.29^{\mathrm{a}}$ & $4.05 \pm 0.17^{\mathrm{b}}$ & $57.60 \pm 0.85^{b}$ \\
\hline $\mathrm{GW}_{\text {shallow }}$ & $34.73 \pm 3.00^{\circ}$ & $4.92 \pm 3.19^{\mathrm{a}}$ & $8.75 \pm 0.08^{\mathrm{c}}$ & $28.8 \pm 0.3^{\mathrm{c}}$ & $\mathrm{nd}^{\mathrm{z}}$ & $19.63 \pm 0.29^{\circ}$ & nd & $7.77 \pm 0.23^{\mathrm{c}}$ & $48.23 \pm 1.42^{\mathrm{c}}$ \\
\hline $\mathrm{GW}_{\text {deep }}$ & $172.33 \pm 0.58^{\mathrm{d}}$ & $10.93 \pm 0.45^{\mathrm{b}}$ & $46.10 \pm 1.13^{\mathrm{d}}$ & $76.7 \pm 0.3^{\mathrm{d}}$ & $0.61 \pm 0.54^{\mathrm{a}}$ & $82.70 \pm 4.33^{\mathrm{d}}$ & nd & nd & $90.23 \pm 2.60^{d}$ \\
\hline
\end{tabular}

${ }^{\mathrm{z}}$ nd, not detected.

Values are means \pm SD $(n=3)$. Different letters for a given parameter indicate significant differences $(P<0.05$, Tukey's-HSD test). 
Table 3 Correlation matrix of physicochemical parameters and ion concentrations of groundwater samples.

\begin{tabular}{lccccccccc}
\hline & $\mathrm{pH}$ & $\mathrm{EC}$ & $\mathrm{ORP}$ & $\mathrm{Na}^{+}$ & $\mathrm{K}^{+}$ & $\mathrm{Mg}^{2+}$ & $\mathrm{Ca}^{2+}$ & $\mathrm{Cl}^{-}$ & $\mathrm{SiO}_{2}$ \\
\hline $\mathrm{pH}$ & 1.00 & & & & & & & & \\
$\mathrm{EC}$ & 0.58 & 1.00 & & & & & & & \\
$\mathrm{ORP}$ & -0.50 & -0.47 & 1.00 & & & & & & \\
$\mathrm{Na}^{+}$ & 0.62 & 0.89 & -0.32 & 1.00 & & & & & \\
$\mathrm{~K}^{+}$ & 0.32 & 0.67 & -0.08 & 0.80 & 1.00 & & & & \\
$\mathrm{Mg}^{2+}$ & 0.69 & 0.80 & -0.22 & 0.94 & 0.74 & 1.00 & & & \\
$\mathrm{Ca}^{2+}$ & 0.53 & 0.86 & -0.14 & 0.88 & 0.85 & 0.91 & 1.00 & & \\
$\mathrm{Cl}^{-}$ & 0.61 & 0.90 & -0.43 & 0.99 & 0.76 & 0.93 & 0.85 & 1.00 & \\
$\mathrm{SiO}_{2}$ & 0.35 & 0.47 & -0.10 & 0.47 & 0.12 & 0.51 & 0.45 & 0.44 & 1.00 \\
\hline
\end{tabular}

EC, electrical conductivity; ORP, oxidation-reduction potential.

samples.

The SAR, a measure of sodium or alkalinity hazard to crops, is an important parameter for determining the suitability of water for use in agricultural irrigation (Subramani et al., 2005). The US salinity laboratory (USSL) diagram (Fig. 2) indicates the EC values that represent a salinity hazard and SAR values that indicate a sodium/alkalinity hazard. USSL quality ratings can be summarized as follows (Richards, 1954; Gaofeng et al., 2010): (1) lowsalinity water $(\mathrm{C} 1)$ can be used for irrigation of most crops in most soils. Some leaching is required, but this occurs under normal irrigation practices, except in soils of extremely low permeability. (2) Medium-salinity water (C2) can be used if a moderate amount of leaching occurs. Plants with moderate salt tolerance can generally be grown without implementing salinity-control practices. (3) Highsalinity water (C3) is acceptable for plants with moderate salt tolerance in moderately permeable soils where leaching occurs. (4) Very high-salinity water (C4) cannot be used on soils with restricted drainage. Even with adequate drainage, special management for salinity control may be required and plants with good salt tolerance should be selected.

Similar to the SAR, evaluations based on sodium hazard follow the guidelines (Richards, 1954; Haritash et al., 2008) that low-sodium water (S1) can be used for irrigation on almost all soils with little danger of developing harmful levels of exchangeable sodium. Medium-sodium water (S2) can present a substantial sodium hazard in some finetextured soils. High-sodium water (S3) may produce harmful levels of exchangeable sodium in most soils and will require special soil management. Very high-sodium water (S4) is generally unacceptable for irrigation.

Following the USSL classification (Fig. 2), $\mathrm{GW}_{\text {shallow }}$ was in category $\mathrm{C} 2 \mathrm{~S} 1$ (medium salinity and low sodium hazard), and thus was suitable for irrigation. In contrast, $\mathrm{GW}_{\text {deep }}$ was classified as C3S1 (high salinity and low sodium hazard). The TW and $\mathrm{GW}_{\text {spring }}$ samples were in category C1S1 (low salinity and low sodium hazard).

\section{Germination tests}

The FG percentage of komatsuna did not differ significantly according to water source (Fig. 3A). However, the early growth of komatsuna was strongly affected by $\mathrm{GW}_{\text {deep }}$. Seedlings grown in $\mathrm{GW}_{\text {deep }}$ were significantly shorter than the other seedlings (Fig. 3B). The use of $\mathrm{GW}_{\text {deep }}$ had a particularly strong effect on root length (Fig. 3C). Root

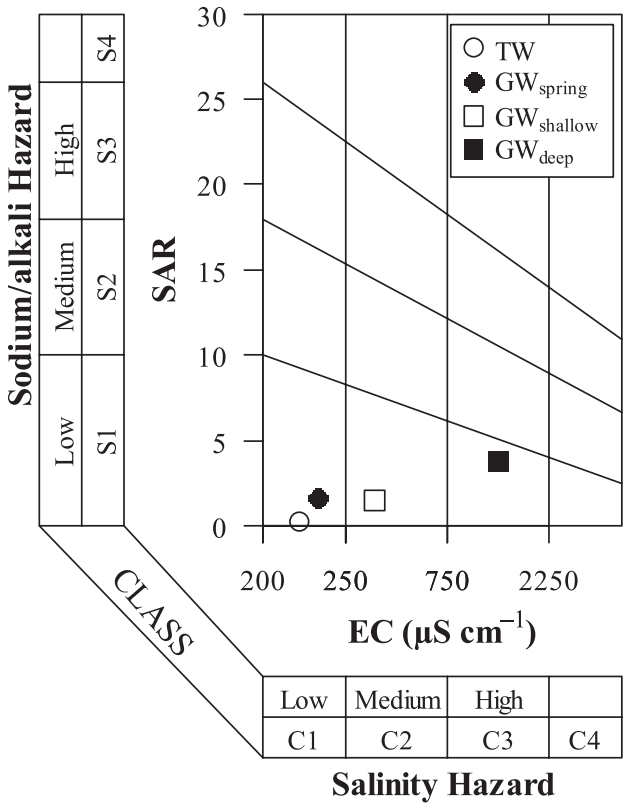

Fig. 2 Plot of calculated values of sodium adsorption ratio (SAR) and electrical conductivity (EC) of groundwater samples (diagram after Rechards, 1954).

growth of plants grown in $\mathrm{GW}_{\text {spring }}(41 \mathrm{~mm})$ was not significantly different from that of plants grown in PW $(36 \mathrm{~mm})$ and TW $(38 \mathrm{~mm})$. Roots of plants grown in $\mathrm{GW}_{\text {shallow }}$ and $\mathrm{GW}_{\text {deep }}$ were significantly shorter compared to those grown in $\mathrm{GW}_{\text {spring. }}$ A strong inhibition of root growth by $\mathrm{GW}_{\text {dee }}$ was observed, with values $44 \%$ lower compared to plants grown in PW. Seedling and root length decreased with increasing depth of the groundwater source. In contrast, shoot length increased significantly with increasing depth of groundwater, from $21 \mathrm{~mm}\left(\mathrm{GW}_{\text {shallow }}\right)$ to $24 \mathrm{~mm}\left(\mathrm{GW}_{\text {deep }}\right)$ (Fig. 3D). In early growth of komatsuna seedlings, $\mathrm{GW}_{\text {deep }}$ had a stronger effect (ethier positive or negative) on seedling, root, and shoot lengths than $\mathrm{GW}_{\text {shallow }}$ and $\mathrm{GW}_{\text {spring. }}$.

Figure 4 illustrates the effects of $\mathrm{NaCl}$ on germination and early growth of komatsuna. A significant effect on FG was observed in $15 \times 10^{3} \mathrm{mg} \mathrm{L}^{-1} \mathrm{NaCl}$ (Fig. 4A). Average seedling growth was more affected than $\mathrm{FG}$ by $\mathrm{NaCl}$ solution. Increases in $\mathrm{NaCl}$ concentration caused a significant decrease in seedling and root lengths of komatsuna (Fig. 4B, C). Compared with the control $\left(0 \mathrm{mg} \mathrm{L}^{-1} \mathrm{NaCl}\right)$, root length was reduced by $94 \%$ in plants grown in $15 \times 10^{3} \mathrm{mg}$ $\mathrm{L}^{-1} \mathrm{NaCl}$. Elongation of seedlings, roots, and shoots was lowest in $15 \times 10^{3} \mathrm{mg} \mathrm{L}^{-1} \mathrm{NaCl}$. Early growth of komatsuna was significantly inhibited at all $\mathrm{NaCl}$ levels (1$15 \times 10^{3} \mathrm{mg} \mathrm{L}^{-1} \mathrm{NaCl}$ ), except for shoot length at $1 \times 10^{3}$ $\mathrm{mg} \mathrm{L}^{-1} \mathrm{NaCl}$ (Fig. 4D). The low-salinity treatment $\left(1 \times 10^{3}\right.$ $\mathrm{mg} \mathrm{L}^{-1} \mathrm{NaCl}$ ) corresponded to significantly increased shoot length. Linear regression analysis showed a significant negative relationship between $\mathrm{NaCl}$ concentration and seedling, root, and shoot length (Table 4). There was also a strong negative relationship $\left(\mathrm{R}^{2}=0.9332, P<0.001\right)$ between $\mathrm{NaCl}$ concentration and seedling length. 

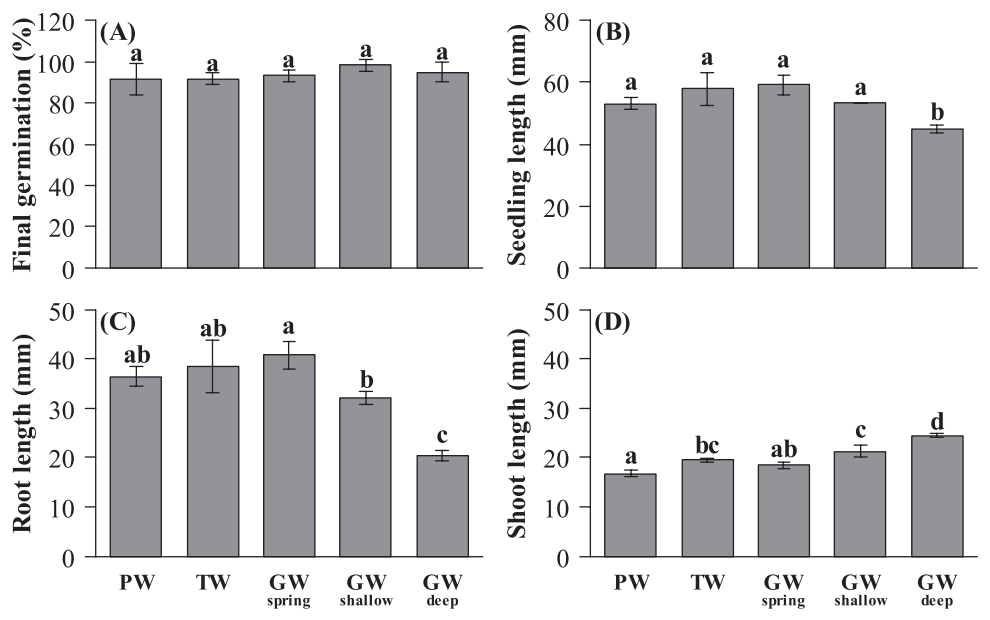

Fig. 3 Effects of pure water (PW), tap water (TW), spring water $\left(\mathrm{GW}_{\text {spring }}\right)$, and deep groundwater $\left(\mathrm{GW}_{\text {shallow }}\right.$ and $\left.\mathrm{GW}_{\text {deep }}\right)$ on germination and early growth of komatsuna. Final germination percentage (A), seedling lengths (B), root lengths (C), and shoot lengths (D) are shown. Values are means; vertical bars represent SD $(n=3)$. Different letters for a given parameter indicate significant differences $(P<0.05$, Tukey's-HSD test).
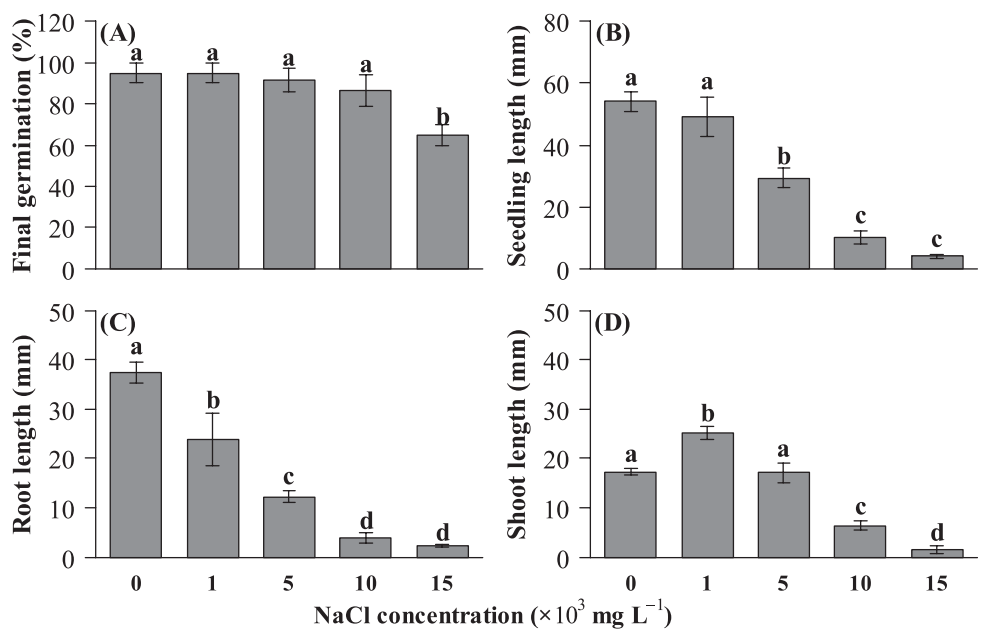

Fig. 4 Effects of salinity $\left(0,1,5,10\right.$, and $\left.15 \times 10^{3} \mathrm{mg} \mathrm{L}^{-1}\right)$ on early growth of komatsuna. Final germination percentage (A), seedling lengths (B), root lengths (C), and shoot lengths (D) are shown. Values are means; vertical bars represent SD ( $n=3)$. Different letters for a given parameter indicate significant differences $(P<0.05$, Tukey's-HSD test).

Table 4 Relationship between $\mathrm{NaCl}$ salinity $\left(\mathrm{x} ; \times 10^{3} \mathrm{mg} \mathrm{L}^{-1}\right)$ and early growth parameters of komatsuna.

\begin{tabular}{lccc}
\hline $\begin{array}{c}\text { Growth parameter } \\
(\mathrm{mm})\end{array}$ & $\begin{array}{c}\text { Liner regression equation } \\
(\text { Growth parameter }=)\end{array}$ & $\begin{array}{c}\text { Regression } \\
\text { coefficient }\left(\mathrm{R}^{2}\right)\end{array}$ & $P$-value \\
\hline Seedling length & $50.915-3.484 \mathrm{x}$ & 0.933 & $<0.001$ \\
Root length & $29.050-2.116 \mathrm{x}$ & 0.796 & $<0.001$ \\
Shoot length & $22.144-1.389 \mathrm{x}$ & 0.847 & $<0.001$ \\
\hline
\end{tabular}

\section{DISCUSSION}

Physicochemical parameters of deep groundwater

Water quality and cropping practices play important roles in irrigation (Ravikumar et al., 2011). Electrical conductivity is a good measure of salinity hazard to plants as it reflects the total dissolved salt in groundwater (Alaya et al., 2013). Good quality irrigation water has values of $\mathrm{EC}<75.0 \mathrm{mS} \mathrm{m}^{-1}$ (Wilcox, 1955). Here, the EC values indicated that $\mathrm{GW}_{\text {spring }}$ and $\mathrm{GW}_{\text {shallow }}$ were suitable for irrigation water, whereas $\mathrm{GW}_{\text {deep }}$ was not ideal but could be marginally acceptable for irrigation (Table 1). The $\mathrm{pH}$ of high- quality irrigation water is generally between 5.4 and 6.8 (Jones, 2005), lower than that observed here for groundwater. However, Kopittke and Menzies (2004) found that root growth of mung beans was only limited in nutrient solution with $\mathrm{pH}>8.5$. Therefore, the $\mathrm{pH}$ of $\mathrm{GW}_{\text {deep }}$ was within permissible limits. Matsuo and Sima (1994a) observed that nutrient solution with low ORP values $\left(115^{-163} \mathrm{mV}\right)$ promoted growth of komatsuna in hydroponic culture, and 300-350 $\mathrm{mV}$ provided optimal growth promotion (Matsuo and Sima, 1994b). Our results indicated that the ORP value of groundwater was close to optimal for growth of komatsuna.

Total hardness is an important criterion in determining 
the suitability of water samples for domestic and industrial purposes (Ravikumar and Somashekar, 2013) and can be used as an indicator of alkalinity. Hard water presents a potential problem since $\mathrm{Ca}^{2+}$ and $\mathrm{Mg}^{2+}$ can combine with bicarbonate to form insoluble carbonate salts. These salts can affect $\mathrm{pH}$ and reduce the amount of sodium available to plants (Robbins, 2010). On the basis of the TH values, only $\mathrm{GW}_{\text {deep }}$ was classified as hard water (Hem, 1970); however, $\mathrm{GW}_{\text {deep }}$ provides a source of $\mathrm{Ca}^{2+}$ and $\mathrm{Mg}^{2+}$ to plants. In general, $\mathrm{Ca}^{2+}$ and $\mathrm{Mg}^{2+}$ in most nutrient solutions fall in the range of $100^{-2} 200$ and $30^{-}-80 \mathrm{mg} \mathrm{L}^{-1}$, respectively in hydroponic systems (Jones, 2005). Therefore, $\mathrm{GW}_{\text {deep }}$ can be adjusted for use in nutrient solutions with hydroponic culture (Table 1). If $\mathrm{GW}_{\text {deep }}$ is used to irrigate highly stress-sensitive plants, it should to be treated (deionized and/or diluted). Appropriate crop selection will help to ensure successful irrigation where untreated groundwater is used.

Excess ions in irrigation water have negative effects on plant growth and agricultural soils, thus reducing productivity. Characteristics that are important in determining the quality of irrigation water include the following: (1) total concentration of salts, (2) relative proportion of sodium ions to other cations, (3) concentrations of toxic elements, and (4) hardness in terms of the concentrations of calcium and magnesium (Richards, 1954). Common problems with irrigation water quality include salinity and alkalinity. Alkalinity hazard was determined by the absolute and relative concentrations of the cations. Therefore, we evaluated the sodium/alkali hazard in terms of SAR. All groundwater samples were classified as excellent for irrigation (S1), indicating that there was no risk of sodium hazard from irrigation with $\mathrm{GW}_{\text {depp }}$. However, on the basis of $\mathrm{EC}$, the salinity hazard of $\mathrm{GW}_{\text {deep }}$ was high (C3; Fig. 2), indicating that control measures would be required if this water source were used for irrigation.

The chemical composition of irrigation water directly affects plant growth and metabolism (Alaya et al., 2013), and the suitability of groundwater for agriculture depends on the effects of its constituent minerals on plant growth. In the present study, groundwater contained essential elements for plant growth (e.g., $\mathrm{K}^{+}, \mathrm{Ca}^{2+}, \mathrm{Mg}^{2+}$, and $\mathrm{Cl}^{-}$; Table 2). In hydroponic culture, most formulated nutrient solutions have fairly low EC $\left(<3.0 \mathrm{dS} \mathrm{m}^{-1}\right)$; for example, Islam et al. (2009) reported that EC of nutrient solutions for komatsuna during the cultivation period ranged from 1.4 to $2.6 \mathrm{dS} \mathrm{m}{ }^{-1}$. Although the concentration of ions in groundwater was higher than of tap water, it was still inadequate for plant growth. The addition of chemical fertilizer would be required for healthy plant growth if groundwater were used because of deficiencies in major elements, including nitrogen, phosphorus, and potassium.

Our results suggested that groundwater could be considered for use in agriculture. Successful irrigation with deep groundwater would require control of salinity stress for plants.

\section{Germination tests}

Seed germination and early growth are normally limited by abiotic stressors such as high salinity and drought
(Almansouri et al., 2001; Jamil et al., 2007; Heidari, 2009). In this study, germination of komatsuna was not affected by use of groundwater (Fig. 3A). Germination was significantly reduced in pepper plants treated with $100-150 \mathrm{mM}$ $\mathrm{NaCl}$ (Chartzoulakis and Klapaki, 2000) and in lettuce subjected to 50-150 mM NaCl (Nasri et al., 2011). However, in durum wheat, moderate stress intensity only delayed germination, whereas high stress intensity had an impact on final germination percentage (Almansouri at el., 2001). Salinity-induced suppression occurs in many plant species, and tolerance to salinity stress varies widely among species. Our study indicated that germination of komatsuna was not inhibited by $\mathrm{NaCl}$ treatments except at high salinity levels $\left(15 \times 10^{3} \mathrm{mg} \mathrm{L}^{-1} \mathrm{NaCl}\right.$; Fig. 4A), suggesting that these treatments generate moderate levels of stress. Because deep groundwater does not have a significant effect on the final germination percentage, it is considered to impose a moderate stress on germination, comparable to the effects of $\mathrm{NaCl}$ treatment.

In general, the growth of most plants is sensitive to salinity stress. The stress induced by salinity results from low osmotic potential (osmotic stress), specific ion toxicity, nutrient imbalances, or a combination of these factors (Almansouri et al., 2001; Murillo-Amador et al., 2002). The reduction in root and shoot length in plants grown in $\mathrm{GW}_{\text {deep }}$ (Fig. 3B, C) and in higher concentrations of $\mathrm{NaCl}$ (Fig. 4B, C) is consistent with general patterns of growth response under saline conditions (Heidari, 2009; Nasri et al., 2011). On the other hand, shoots of plants grown in groundwater were longer than those grown in PW and TW (Fig. 3D) and shoots of plants grown in $1 \times 10^{3} \mathrm{mg} \mathrm{L}^{-1}$ $\mathrm{NaCl}$ solution were longer than those of control plants (Fig. 4D). Similar trends in shoot growth under low concentrations of $\mathrm{NaCl}$ were reported for bitter vetch (Çöçü and Uzun, 2011). In contrast, root length was inhibited by moderate levels of salinity in groundwater (Fig. 3B). Root elongation is generally more sensitive to salinity and drought stress than shoot growth. High sensitivity to salt was observed in roots of cabbage (Jamil et al., 2007) and lettuce (Nasri et al., 2011). Roots are in direct contact with salinity in solution, and thus are the first sites at which damage occurs under salt stress. We observed a significant negative relationship between $\mathrm{NaCl}$ concentration and seedling, root, and shoot length (Table 4), similar to observations made in cabbage (Jamil et al., 2007).

In conclusion, electrical conductivity, total hardness, sodium adsorption ratio, and concentration of ions increased with increasing groundwater depth. Deep groundwater in the Sambagawa Belt is acceptable for irrigation, representing a low sodium hazard and high salinity hazard. We observed that growth of komatsuna in $\mathrm{GW}_{\text {deep }}$ was similar to that in $1 \times 10^{3} \mathrm{mg} \mathrm{L}^{-1} \mathrm{NaCl}$ solution. The salinity level of groundwater was moderate for germination and early seedling growth of komatsuna. This groundwater source can be used to control early growth of komatsuna but not final germination percentage. This control of early growth would facilitate high-quality agricultural production because of moderate environmental stress, including salinity stress. Generally, solutes such as amino acids and 
soluble sugars accumulate in plant tissues and help to prevent water loss under salinity stress (Verslues et al, 2006). This accumulation can help to improve the quality of the commercial crop.

\section{REFERENCES}

Alaya, M. B., Saidi, S., Zemni, T., Zargouni, F. 2013. Suitability assessment of deep groundwater for drinking and irrigation use in the Djeffara aquifers (Northern Gabes, southeastern Tunisia). Environ. Earth Sci. doi: 10.1007/s12665013-2729-9.

Alley, W. M., Bair, E. S., Wireman, M. 2013. "Deep” groundwater. Groundwater 51: 653-654.

Almansouri, M., Kinet, J.-M., Lutts, S. 2001. Effect of salt and osmotic stresses on germination in durum wheat (Triticum durum Desf.). Plant Soil 231: 243-254.

Chartzoulakis, K., Klapaki, G. 2000. Response of two greenhouse pepper hybrids to $\mathrm{NaCl}$ salinity during different growth stages. Sci. Hortic. 86: 247-260.

Çöçï, S., Uzun, O. 2011. Germination, seedling growth and ion accumulation of bitter vetch (Vicia ervilia (L.) Wild.) lines under NaCl. Afr. J. Biotechnol. 10: 15869-15874.

Gaofeng, Z., Yonghong, S., Chunlin, H., Qi, F., Zhiguang, L. 2010. Hydrogeochemical processes in the groundwater environment of Heihe River Basin, northwest China. Environ. Earth Sci. 60: 139-153.

Giridharan, L., Venugopal, T., Jayaprakash, M. 2008. Evaluation of the seasonal variation on the geochemical parameters and quality assessment of the groundwater in the proximity of River Cooum, Chennai, India. Environ. Monit. Assess. 143: 161-178.

Haritash, A. K., Kaushik, C. P., Kaushik, A., Kansal, A., Yadav, A. K. 2008. Suitability assessment of groundwater for drinking, irrigation and industrial use in some North Indian villages. Environ. Monit. Assess. 145: 397-406.

Hayward, H. E., Bernstein, L. 1958. Plant-growth relationships on salt-affected soils. Bot. Rev. 24: 584-635.

Hebig, K. H., Ito, N., Scheytt, T., Marui, A. 2012. Deep groundwater research with focus on Germany. Hydrogeol. J. 20: 227-243.

Heidari, M. 2009. Variation in seed germination, seedling growth, nucleic acid and biochemical component in canola (Brassica napus L.) under salinity stress. Asian J. Plant Sci. 8: 557-561.

Hem, J. D. 1970. Study and interpretation of the chemical characteristics of natural water 2 nd ed. US government printing office, Wahington, p 224-226.

Islam, S., Kazunori, K., Takeda, N., Ishikawa, K. 2009. High quality komatsuna (Brassica rapa L. nothovar) production by using silicate minerals treated nutrient solution. Am. J. Agric. Biol. Sci. 4: 12-17.

Jamil, M., Lee, K. B., Jung, K. Y., Lee, D. B., Han, M. S., Rha, E. S. 2007. Salt stress inhibits germination and early seedling growth in cabbage (Brassica oleracea capitata L.). Pak. J. Biol. Sci. 10: 910-914.

Jones, J. B. Jr. 2005. Hydroponics: a practical guide for the soilless grower 2nd ed. CRC Press, Boca Raton, Florida, pp $76,83$.

Kanae, S. 2009. Global warming and water crisis. J. Health Sci. 55: $860-864$.

Ketata, M., Gueddari, M., Bouhlila, R. 2012. Suitability assessment of shallow and deep groundwaters for drinking and irrigation use in the EI Khairat aquifer (Enfidha, Tunisian Sahel). Environ. Earth Sci. 65: 313-330.
Kopittke, P. M., Menzies, N. W. 2004. Control of nutrient solutions for studies at high pH. Plant Soil 266: 343-354.

Kumar, M., Ramanathan, A. L., Rao, M. S., Kumar, B. 2006. Identification and evaluation of hydrogeochemical processes in the groundwater environment of Delhi, India. Environ. Geol. 50: 1025-1039.

Ling, T., Fangke, Y., Jun, R. 2010. Effect of mercury to seed germination, coleoptile growth and root elongation of four vegetables. Res. J. Phytochem. 4: 225-233.

Matsuo, M., Sima, A. 1994a. Effects of electrolytic water on the growth of soilless culture plant (2) -Effects of solution diluted by electrolytic water on the growth of komatsuna in soilless culture-. (in Japanese with English abstract) J. SHITA 6: 134-141.

Matsuo, M., Sima, A. 1994b. Effects of electrolytic water on the growth of soilless culture plant (3) -Effects of oxidation reduction potential of electrolytic water on the growth of komatsuna in soilless culture- (in Japanese with English abstract) J. SHITA 6: $142-146$.

Mitra, B. K., Sasaki, C., Enari, K., Matsuyama, N., Fujita, M. 2007a. Suitability assessment of shallow groundwater for agriculture in sand dune area of northwest Honshu Island, Jpn. Appl. Ecol. Environ. Res. 5: 177-188.

Mitra, B. K., Sasaki, C., Enari, K., Matsuyama, N., Pongpattanasiri, S. 2007b. Groundwater quality in sand dune area of northwest Honshu Island in Japan. J. Agron. 6: $81-87$.

Murillo-Amador, B., López-Aguilar, R., Kaya, C., LarrinagaMayoral, J., Flores-Hernández, A. 2002. Comparative effects of $\mathrm{NaCl}$ and polyethylene glycol on germination, emergence and seedling growth of cowpea. J. Agric. Crop Sci. 188: $235-247$.

Nahar, M. S., Zhang, J. 2012. Assessment of potable water quality including organic, inorganic, and trace metal concentrations. Environ. Geochem. Health 34: 141-150.

Nasri, N., Kaddour, R., Rabhi, M., Plassard, C., Lachaal, M. 2011. Effect of salinity on germination, phytase activity and phytate content in lettuce seedling. Acta Physiol. Plant 33: 935-942.

Ongley, E. D. 1996. Control of water pollution from agriculture. FAO, Rome, Italy, p 1.

Pereira, L. S., Oweis, T., Zairi, A. 2002. Irrigation management under water scarcity. Agric. Water Manag. 57: 175-206.

Rahman, M. A. T. M. T., Majumder, R. K., Rahman, S. H., Halim, Md. A. 2011. Sources of deep groundwater salinity in the southwestern zone of Bangladesh. Environ. Earth Sci. 63: 363-373.

Ravikumar, P., Somashekar, R. K. 2013. A geochemical assessment of coastal groundwater quality in the Varahi River Basin, Udupi District, Karnataka State, India. Arab. J. Geosci. 6: $1855-1870$.

Ravikumar, P., Somashekar, R. K., Angami, M. 2011. Hydrochemistry and evaluation of groundwater suitability for irrigation and drinking purposes in the Markandeya River Basin, Belgaum District, Karnataka State, India. Environ. Monit. Assess. 173: 459-487.

Richards, L. A. 1954. Diagnosis and improvement of saline and alkali soils. USDA, Hand-book no. 60. U.S. Salinity Laboratory, Washington, DC, pp 79.

Robbins, J. 2010. Irrigation water for greenhouses and nurseries. U.S. Dept. of Agriculture, and Country Governments Cooperating no.6061. Agriculture and Natural Resources, University of Arkansas, Division of Agriculture, Arkansas, $\mathrm{p} 3$.

Scanlon, B. R., Jolly, I., Sophocleous, M., Zhang, L. 2007. Global impacts of conversions from natural to agriculture ecosystems on water resources: quantity versus quality. Water 


\section{HIKASHI AND K. ISHIKAWA}

Resour. Res. 43: W03437, doi: 10.1029/2006WR005486.

Shah, T., Roy, A. D., Qureshi, A. S., Wang, J. 2003. Sustaining Asia's groundwater boom: an overview of issues and evidence. Nat. Resour. Forum 27: 130-140.

Subramani, T., Elango, L., Damodarasamy, S. R. 2005. Groundwater quality and its suitability for drinking and agricultural use in Chithar River Basin, Tamil Nadu, India. Environ. Geol. 47: 1099-1110.

Verslues, P. E., Agarwal, M., Katiyar-Agarwal, S., Zhu, J., Zhu, J.K. 2006. Methods and concepts in quantifying resistance to drought, salt and freezing, abiotic stresses that affect plant water status. Plant J. 45: 523-539.
Wilcox, L. V. 1955. Classification and use of irrigation waters. USDA, Circular 969, Washington, DC, p 7.

Zamberlan da Silva, M. E., Santana, R. G., Guilhermetti, M., Filho, I. C., Endo, E. H., Ueda-Nakamura, T., Nakamura, C. V., Filho, B. P. D. 2008. Comparison of the bacteriological quality of tap water and bottled mineral water. Int. J. Hyg. Environ. Health 211: 504-509.

Zhang, H., Irving, L. J., McGill, C., Matthew, C., Zhou, D., Kemp, P. 2010. The effects of salinity and osmotic stress on barley germination rate: sodium as an osmotic regulator. Ann. Bot. 106: 1027-1035. 